\title{
MEMBANDINGKAN METODE SIMPLEKS DAN LINPROG
}

\author{
Ulul Ilmi \\ Program Studi Teknik Informatika - Universitas Muhammadiyah Gresik
}

\begin{abstract}
Abstrak
Penelitian ini bertujuan membandingkan antara metode simpleks dan linprog guna merancang usaha tani untuk menemukan nilai optimisasi pada masalah pemrograman linear (linear programming) dengan menggunakan software matlab. Kriteria keberhasilan penelitian ini didasarkan pada ketepatan nilai fungsi objektif dan beban komputasi yang dihasilkan oleh kedua metode itu. Penelitian ini mengambil tempat di Instansi Dinas Pertanian dan Kehutanan Kecamatan Paciran.

Dalam penyelesaiannya, linear programming menuntut fungsi tujuan bernilai optimal (maksimum atau minimum) nonnegative yang tunduk pada variabel pembatas.

Hasil eksekusi simulasi linear programming menunjukkan metode linprog yang di hasilkan melalui software matlab menghasilkan beban komputasi yang lebih kecil jika dibandingkan dengan metode simpleks yang juga disimulasikan memakai software matlab

Kata Kunci : Pemrograman linear, usaha tani, metode simpleks, fungsi objektif
\end{abstract}

\section{A. PENDAHULUAN}

Mosher (1983) menjelaskan bahwa usaha tani adalah usaha dari sebidang tanah beserta bangunan - bangunan yang dibuat diatasnya seperti saluran irigasi, kandang ternak, gudang, rumah tempat tinggal petani dan sebagainya, dimana seorang petani atau sebuah keluarga petani atau badan usaha lain bercocok tanam atau memelihara ternak.

Untuk menjalankan usaha tani dibutuhkan sumber daya alam. Pengertian sumber daya alam adalah kemampuan atau unsur yang digunakan untuk memproduksi hasil. Soekartawi (1987) menjelaskan bahwa sumber daya ada 4 macam yaitu :

1. Tanah. Tanah adalah sumber daya alami yang dipakai dalam proses produksi. Dalam penelitian optimisasi usaha tani keluarga di Kabupaten Kediri didapatkan bahwa lahan merupakan sumber daya yang langka (Syafaat, 1997). Peningkatan sumber daya lahan tidak harus dilakukan dengan ekstensifikasi, tetapi dapat dilakukan melalui peningkatan intensitas tanaman.

2. Tenaga kerja. Tenaga kerja adalah semata - mata tenaga kerja yang dipakai secara fisik, yaitu tenaga kerja yang dapat dipekerjakan untuk menjalankan berbagai tugas operasional.

3. Modal. Pengertian modal adalah kekayaan baik yang berupa barang atau uang yang digunakan dalam proses produksi yang bersama - sama faktor produksi lain menghasilkan barang baru. Pembentukan modal mempunyai tujuan untuk menunjang pembentukan lebih lanjut dan untuk meningkatkan produksi dan pendapatan usaha tani. 
4. Manajemen. Manajemen atau pengelolaan dalam usaha tani adalah kemampuan petani dalam menentukan dan mengorganisir

faktor - faktor produksi yang dikuasai sebaik - baiknya dan mampu memberikan produksi pertanian yang diharapkan.

\section{B. PERUMUSAN MASALAH}

Dari pendahuluan diatas, permasalahan yang dihadapi petani adalah pada penentuan tingkat penggunaan sumber daya atau input yang dapat menekan biaya serendah - rendahnya dan dapat menghasilkan keuntungan atau pendapatan yang maksimal prinsip semacam ini disebut sebagai prinsip optimisasi dalam usaha tani.

\section{MAKSUD DAN TUJUAN PENELITIAN}

Maksud dan tujuan melakukan penelitian ini adalah:

1. Merancang usaha tani berbasis linear programming

2. Membandingkan beban komputasi dan fungsi objektif yang dihasilkan oleh metode simpleks dan linprog yang kedua anya disimulasikan dengan memakai matlab.

\section{METODE PENELITIAN}

Dalam penelitian ini metode yang dilakukan untuk memperoleh hasil yang diharapkan selama penelitian adalah sebagai berikut :

1. Studi literatur, terutama yang berkaitan dengan metode simpleks dan linear programming.

2. Menyiapkan rancangan untuk menyusun prinsip optimisasi dalam usaha tani menggunakan sistem operasi berbasis windows 98. Penulis juga menginstal dua komputer client berbasis Windows 98 dan Windows 2000.

3. Mendesain dan menulis kode program berbasis linear programming.

4. Diskusi dengan pembimbing, pengguna mathlab terutama pemrogram linear programming.

\section{E. TINJAUAN PUSTAKA Pemrograman Linear}

Pemrograman Linear merupakan suatu metode matematik dalam mengalokasikan sumber daya yang langka untuk mencapai suatu tujuan. Program tersebut disebut linear karena hubungan dari unsur - unsur yang terkait adalah linear.

Levin et.al. (1995) menyatakan bahwa Pemrograman Linear merupakan teknik matematika untuk mendapatkan alternatif penggunaan terbaik atas sumber - sumber organisasi. Program menyatakan penggunaan teknik matematika tertentu untuk mendapatkan kemungkinan pemecahan terbaik atas persoalan yang melibatkan sumber yang serba terbatas. Welche dan Commer (1983) menyatakan Pemrograman Linear merupakan teknik untuk menghitung kombinasi optimum dari sumber - sumber tertentu agar dapat tercapai tujuan yang semaksimal mungkin sebagaimana yang telah ditetapkan sebelumnya. 
Levin et.al. (1995), menyatakan penggunaan Pemrograman Linear sebagai teknik pengambilan keputusan menggunakan pendekatan tiga tahap proses sebagai berikut :

a. Perumusan masalah ; mengumpulkan informasi yang sesuai, mempelajari pertanyaan apa yang harus dijawab, dan membuat permasalahan ke dalam bentuk Pemrograman Linear.

b. Pemecahan masalah ; mencari pemecahan optimal Pemrograman Linear.

c. Interpretasi dan penerapan solusi.

Levin et.al. (1995) menyatakan bahwa persyaratan utama dalam pemecahan masalah Pemrograman Linear adalah sebagai berikut :

a. Memiliki tujuan. Tujuan dari sebuah permasalahan Pemrograman Linear berupa bentuk memaksimisasi keuntungan (laba) atau minimisasi biaya.

b. Harus ada alternatif tindakan salah satu darinya untuk mencapai tujuan.

c. Sumber yang diperhitungkan dalam model merupakan persediaan terbatas.

d. Tujuan dan segenap keterbatasannya dinyatakan dalam bentuk persamaan atau pertidaksamaan matematika.

\section{Bentuk Umum Pemrograman Linear}

Bentuk pemrograman linear dapat digambarkan sebagai berikut :

Mengoptimalkan fungsi tujuan berdasarkan kendala - kendala yang diberikan. Kendala kendala yang diberikan adalah suatu fungsi dari variabel - variabel bebas yang merupakan variabel keputusan. Solusi optimal dari Pemrograman Linear adalah ditemukan nilai variabel keputusan yang memenuhi fungsi tujuan. Bentuk umum dari Pemrograman Linear adalah sebagai berikut :

$\begin{array}{lll}\text { Optimalkan } & \mathrm{Z}=\mathrm{c}_{1} \mathrm{x}_{1}+\mathrm{c}_{2} \mathrm{x}_{2}+\ldots+\mathrm{c}_{\mathrm{n}} \mathrm{x}_{\mathrm{n}}=\sum_{j=1}^{n} \mathrm{c}_{\mathrm{j}} \mathrm{x}_{\mathrm{j}} \\ \text { Kendala } & \mathrm{a}_{11} \mathrm{x}_{1}+\mathrm{a}_{12} \mathrm{x}_{2}+\ldots+\mathrm{a}_{1 \mathrm{n}} \mathrm{x}_{\mathrm{n}} \leq \mathrm{b}_{1} \\ & \cdot & \\ & \mathrm{a}_{\mathrm{m} 1} \mathrm{x}_{1}+\mathrm{a}_{\mathrm{m} 2} \mathrm{x}_{2}+\ldots+\mathrm{a}_{\mathrm{mn}} \mathrm{x}_{\mathrm{n}} \leq \mathrm{b}_{\mathrm{m}} \\ & \mathrm{x}_{1}, \mathrm{x}_{2}, \ldots, \mathrm{x}_{\mathrm{n}} \geq 0 & \\ \text { dengan } & \mathrm{x}_{1}, \mathrm{x}_{2}, \ldots, \mathrm{x}_{\mathrm{n}} & =\text { variabel keputusan } \\ & \mathrm{Z} & =\text { fungsi tujuan } \\ & \mathrm{c}_{1}, \mathrm{c}_{2}, \ldots, \mathrm{c}_{\mathrm{n}} & =\text { koefisien variabel keputusan pada fungsi } \\ & & \text { tujuan } \\ & \mathrm{a}_{\mathrm{m} 1}, \mathrm{a}_{\mathrm{m} 2}, \ldots, \mathrm{a}_{\mathrm{mn}} & =\text { koefisien variabel keputusan pada kendala } \\ & \mathrm{b} 1, \mathrm{~b} 2, \ldots, \mathrm{bm} & =\text { batas kendala. }\end{array}$

\section{F. PERANCANGAN MODEL}

\section{Kondisi Sistem Usaha Tani}

Kondisi system usaha tani yang ada di daerah penelitian masih bersifat tradisional yang bermakna bahwa masyarakat di daerah tersebut masih terjebak pada rutinitas tahunan dalam mengelola usaha tani. Masyarkat di daerah penelitian jika ditinjau dalam pengamatan sehari - hari belum bisa memikirkan suatu cara untuk meminimalkan biaya usaha tani. Bertolak dari hal inilah maka akan dirancang suatu model yang diharapkan nantinya bisa dipakai sebagai patokan untuk meminimalkan biaya usaha tani. 


\section{Data Percobaan}

Tabel 1. Analisa Usaha Tani di Dinas Pertanian dan Kehutanan Kecamatan Deket musim panen 1 tahun 2002

\begin{tabular}{|c|c|c|c|c|}
\hline No & Uraian & $\mathrm{HOK} / \mathrm{Kg}$ & $\begin{array}{c}\text { Harga satuan } \\
\text { (Rp) }\end{array}$ & Nilai Total (Rp) \\
\hline 1 & 2 & 3 & 4 & 5 \\
\hline \multirow[t]{6}{*}{$\mathrm{A}$} & Sarana Produksi & & & \\
\hline & 1.Benih Hibrida & $15 \mathrm{~kg}$ & 23.000 & 345.000 \\
\hline & 2. Pupuk - Urea & $350 \mathrm{~kg}$ & 1.150 & 402.500 \\
\hline & - SP 36 & $100 \mathrm{~kg}$ & 1.500 & 150.000 \\
\hline & - Organik / Kandang & $4000 \mathrm{~kg}$ & 50 & 200.000 \\
\hline & Jumlah Sarana Produksi (A) & & & 1.097 .500 \\
\hline \multirow[t]{10}{*}{$\mathrm{B}$} & Tenaga Kerja & & & \\
\hline & 1. Pengolahan tanah - bajak & & & 420.000 \\
\hline & - cangkul & $4 \mathrm{TKP}$ & 17.500 & 70.000 \\
\hline & 2. Menanam & 4 TKP & 35.000 & 140.000 \\
\hline & & $6 \mathrm{TKW}$ & 15.000 & 90.000 \\
\hline & 3. Memupuk & $10 \mathrm{TKP}$ & 17.500 & 175.000 \\
\hline & 4. Menyiang & $58 \mathrm{TKP}$ & 15.000 & 870.000 \\
\hline & 5. Panen & $30 \mathrm{TKP}$ & 17.500 & 525.000 \\
\hline & & 10 TKW & 17.500 & 175.000 \\
\hline & Jumlah Tenaga Kerja (B) & & & 2.465 .000 \\
\hline $\mathrm{C}$ & Sewa tanah & & 450.000 & 450.000 \\
\hline $\mathrm{D}$ & Pajak & & 11.000 & 11.000 \\
\hline
\end{tabular}




\begin{tabular}{|l|l|r|r|r|}
\hline E & Total biaya (A + B + C + D) & & & 4.023 .500 \\
\hline F & Produksi & $5000 \mathrm{~kg}$ & 935 & 4.675 .000 \\
\hline G & Return of Cost & & & 1,16 \\
\hline H & Keuntungan (F - E) & & & 651.500 \\
\hline I & Pendapatan $(\mathrm{C}+\mathrm{I})$ & & & 1.101 .500 \\
\hline
\end{tabular}

\section{Perancangan Penyusunan Model Linear Programming (LP)}

Berdasarkan hasil studi pustaka dan studi lapangan tersebut maka dibuat suatu pedoman untuk perancangan model linear programming. Pedoman ini dibuat didasarkan dari data sekunder yang dihasilkan oleh dinas Pertanian dan Kehutanan serta dari hasil pengamatan sehari - hari sebagai bagian dari fase perencanaan dan selanjutnya akan dimasukkan. Adapun langkah - langkah perancangan model dilakukan sebagai berikut :

1. Perumusan Masalah

Masalah yang hendak dirumuskan masalah optimisasi usaha tani.

2. Penentuan Tujuan Penelitian

Dalam hal ini tujuan penelitian yang hendak dicapai adalah bagaimana membuat suatu model untuk meminimalkan biaya usaha tani.

3. Perancangan Usaha Tani

Rancangan yang hendak dibuat adalah perancangan model berbasis linear programming. dan selanjutnya dari fase perancangan ini akan dimasukkan ke fase implementasi.

\section{G. IMPLEMENTASI MODEL}

Implementasi model dilakukan melalui langkah - langkah sebagai berikut :

1. Penulisan usaha tani dalam bentuk linear programming

2. Penulisan usaha tani dalam bentuk $A x=b$

3. Penyelesaian dengan metode simpleks dan linprog

4. Membandingkan beban komputasi dan fungsi objektif yang dihasilkan oleh metode tersebut.

Dari hasil penelitian menunjukkan beban komputasi yang dihasilkan oleh metode simpleks lebih besar jika dibandingkan dengan linprog. Dengan demikian dapat disimpulkan dalam penyelesaian masalah linear programming yang masih mempertimbangkan masalah komputasi maka dianjurkan memakai metode linprog.

\section{H. PENUTUP}

Melalui perancangan usaha tani berbasis linear programming maka diharapkan dapat dipakai untuk pemecahan masalah optimisasi pada bidang kehidupan yang lain. Diharapkan dapat dilakukan pengembangan penelitian masalah - masalah yang berkaitan 
dengan optimisasi dengan memakai metode yang lain yang natinya akan melengkapi dan menyempurnakan penelitian ini.

\section{DAFTAR PUSTAKA}

Bedeian Arthur, 1984. Organization Theory and Analysis : Text and Cases. Second Edition, Hold - Sanders International Edition, Japan.

Bernard W.Taylor III, Chaerul D.Djakman, S.E., Ak., M.B.A. dan Vita Silvira, S.E., M.B.A., 2001. Sains Manajemen. Edisi kedua, Salemba Raya, Jakarta.

Dadan Umar Daihani, 2001. Komputerisasi Pengambilan Keputusan. Elex Media Komputindo, Jakarta.

F. Soesianto, 2002. Linear Programming. Program Pasca Sarjana. Jurusan Teknik Elektro UGM, Yogyakarta.

Introduction to Linear Programming, http://helios.bto.ed.ac.uk/resman/nrm/LP/introduction_to_linear_programming.htm.

Soekartawi, 1995. Linear Programming Teori dan Aplikasinya, Khususnya dalam Bidang Pertanian. Rajawali Press Jakarta. 